\title{
Wood anatomy of tribe Detarieae and comparison with tribe Caesalpinieae (Leguminosae, Caesalpinioideae) in Venezuela
}

\author{
José Luis Melandri ${ }^{1,2}$ \& Narcisana Espinoza de Pernía ${ }^{1}$ \\ 1. Laboratorio de Anatomía de Maderas, Facultad de Ciencias Forestales y Ambientales. Universidad de Los Andes, \\ Mérida, Venezuela, melandri@ula.ve,nepernia@ula.ve \\ 2. Author for correspondence: melandri@ula.ve
}

Received 28-II-2008. C Corrected 06-VII-2008. Accepted 04-VIII-2008.

\begin{abstract}
We studied the wood anatomy of 29 species belonging to 10 genera of the tribe Detarieae, subfamily Caesalpinioideae and compare them with tribe Caesalpinieae. Detarieae is the largest of four tribes of Caesalpinioideae, with 84 genera, only eleven occur in Venezuela with species of timber importance. The specimens were collected in Venezuela and include wood samples from the collection of the Laboratorio de Anatomía de Maderas de la Facultad de Ciencias Forestales y Ambientales de la Universidad de Los Andes, Venezuela, and of the Forest Products Laboratory of the USDA Forest Service in Madison, Wisconsin, USA. The terminology and methodology used followed the IAWA List of Microscopic Features for Hardwood Identification of the IAWA Committee, 1989. Measurements from each specimen were averaged (vessel diameters, vessel element lengths, intervessels pit size, fibre lengths and ray height). The species of Detarieae can be separated using a combination of diagnostic features. Wood characters that provide the most important diagnosis and may be used in systematics of Detarieae include: intercellular axial canals, rays heterocellular, rays exclusively or predominantly uniseriate, prismatic crystals common in ray cells, irregular storied structure and fibre wall thickness. For comparative anatomy between Detarieae and Caesalpinieae: intercellular axial canals, heterocellular rays, rays exclusively or predominantly uniseriate, prismatic crystals common in ray cells (in Detarieae) and regular storied structure, fibres septate, fibre wall thick or very thick, rays homocellular, multiseriate rays and silica bodies (in Caesalpinieae). Axial parenchyma is typically a good diagnostic feature for Leguminosae, but not for Detarieae and Caesalpinieae comparisons. Rev. Biol. Trop. 57 (1-2): 303-319. Epub 2009 June 30.
\end{abstract}

Key words: Leguminosae, Caesalpinioideae, Detarieae, Caesalpinieae, wood anatomy, identification.

The legume tribe Detarieae is the largest of four tribes of subfamily Caesalpinioideae, comprises 84 genera including approximately half of the genera of subfamily Caesalpinioideae. Most of these genera occur in tropical Africa, with a less diverse representation in tropical America and Asia (Barneby et al. 1998, Bruneau et al. 2000, Herendeen 2000, Gasson et al. 2003, Herendeen et al. 2003,). Only eleven genera of the Detarieae tribe are distributed in Venezuela (Barneby et al. 1998, Aristeguieta 2003). Wood anatomy study of the tribes, genera or species in the subfamily Caesalpinioideae that have attempted to identify important wood characters for taxonomic, systematic and properties of commercial timbers purposes include Reinders-Gouwentak (1955), BarettaKuipers (1981), Ranjani and Krishnamurthy (1988), Détienne and Welle (1989), Wheeler and Baas (1992), Nardi and Edlmann (1992), Gasson (1994), (1996), (1999), Höhn (1999), Herendeen (2000), Miller and Détienne (2001), Chauhan and Rao (2003), Gasson et al. (2003), Espinoza de Pernía and Melandri (2006a,b).

Some genera of the tribe Detarieae yield commercial timbers, particularly Copaifera, Eperua, Hymenaea, and Peltogyne, this last is known as "Purpleheart" high-quality wood 
that is widely appreciated for its unusual color and resistance to insects (JUNAC 1981, INIA 1996, Barneby et al. 1998, Aristeguieta 2003). Others genera such as Brownea and Dicymbe are important ornamental trees, in gardens, city avenues and parks (Barneby et al. 1998, Aristeguieta 2003). Medicinal plants such as Copaifera are of high industrial value for their gum or balsam of Copaiba for medical treatments, manufacturing of varnishes and shellacs, and as a fixative of fragrances in soaps and perfumes. The Elizabetha genus yields a hallucinogenic drug, while Hymenaea genus is used for food and forage, medical treatments, canoe building and manufacturing of varnishes (Mabberley 1997, Barneby et al. 1998, Aristeguieta 2003). Some Dicymbe, Eperua, Heterostemom and Macrolobium species are endemic to the Venezuelan Guayana (Barneby et al. 1998).

This paper provides information about wood anatomy of native genera of the tribe Detarieae, that has not been adequately studied, and to compare them with the tribe Caesalpinieae (Espinoza de Pernía and Melandri 2006b). The microscopic wood anatomy of both tribes was studied because of its great importance in the timber industry and the complexity of its anatomy. The anatomical descriptions provide tools for the identification of the genera and groups within the tribe.

\section{MATERIALS AND METHODS}

Microscope slides from 70 wood samples representing 28 species from 10 genera the tribe Detarieae were examined (only 11 genera of the tribe are distributed in Venezuela: Brownea, Copaifera, Crudia, Cynometra, Dicymbe, Elizabetha, Eperua, Heterostemon, Hymenaea, Macrolobium, Peltogyne). The majority of the specimens were collected in Venezuela and includes specimens from the wood collection at the Laboratorio de Anatomía de Maderas de la Facultad de Ciencias Forestales y Ambientales de la Universidad de Los Andes, Mérida, Venezuela (MERw) and at the USDA Forest Service, Forest Products Laboratory, Madison, Wisconsin, USA (MADw and SJRw).
We followed the List of Microscopic Features for Hardwood Identification (IAWA Committee 1989) for terminology and methodology. The following characters were recorded for each specimen studied: presence/absence of growth rings, porosity, vessels distribution, intervessels pit size, vestured pits, fibre wall thickness, septate fibres, axial parenchyma patterns, number of the cells per axial parenchyma strand, ray size in height and width in cells, composition ray cell, storeyed structure, prismatic crystals, silica bodies, and axial canal, among others characters. Generic descriptions follow in alphabetical order and features not listed in the generic descriptions are either absent or do not apply. For vessel diameters, vessel element lengths, fibre lengths and ray height 25 measurements were taken from each specimen and averaged. The measurements are accurate only to the 10 um level, and are reported accordingly. The values reported [e.g. 30 (50-110) $150 \mu \mathrm{m}$ ], are minimum value, range of averages, and maximum value. For other quantitative values the most frequent range is reported. Photomicrographs were taken using a film camera with a light microscope.

\section{RESULTS}

\section{Generic descriptions}

\section{Brownea Jacq. - Fig. $1 \& 2$}

Growth rings distinct, marked by marginal parenchyma bands and/or thick-walled fibres. Diffuse porous. Vessels solitary and in radial multiples of 2-4, 3-17 per $\mathrm{mm}^{2}$, 40(70128) $160 \mu \mathrm{m}$ in diameter, 130(209-372)550 $\mu \mathrm{m}$ in element length. Simple perforation plates. Alternate intervessel pits circular or oval and polygonal, minute to small, 3-6 $\mu \mathrm{m}$ in diameter. Vessel-ray pits with distinct borders, similar to intervessel pits in size and shape, pits vestured. Brown gum-like deposits in vessels. Fibres non-septate, medium- to thick-walled, 700(908-1436)1680 $\mu \mathrm{m}$ in length. Axial parenchyma vasicentric (in $B$ coccinea), aliform to 

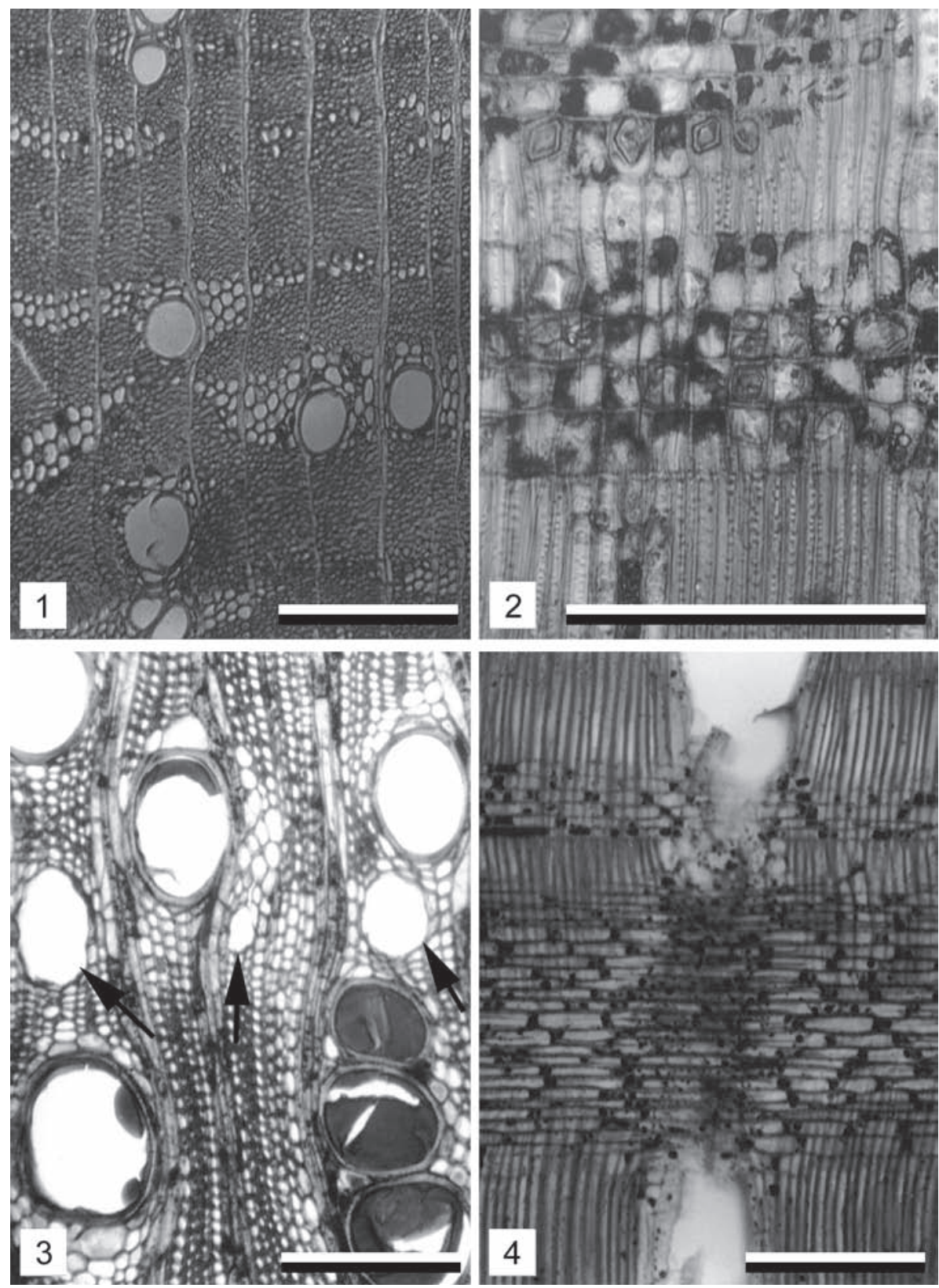

Fig. 1-4. (1 \& 2): Brownea species.- 1: B. coccinea, aliform, confluent parenchyma.- 2: B. grandiceps, rays heterocellular and prismatic crystals in chambered ray cells.- $3 \& 4$ : Copaifera species.- 3: C. officinalis, intercellular axial canals (arrow) in long tangential lines, brown gum-like deposits in vessels.- 4: C. pubiflora, homocellular rays composed of typically procumbent cells. Scale bars $=250 \mu \mathrm{m}$. 
confluent in all species, aliform parenchyma of the lozenge type. Banded parenchyma of more than three cells wide in $B$. grandiceps and $B$. macrophylla. Marginal parenchyma bands present. Axial parenchyma 3-6 cells per parenchyma strand. Rays heterocellular with 1 to 2 rows of upright and/or square marginal cells, 9-20 per mm, exclusively (in B. coccinea) or mostly uniseriate (in $B$. grandiceps, $B$. macrophylla), 120(252-340)600 $\mu \mathrm{m}$ in height. Prismatic crystals common in ray cells (both upright and/or square and procumbent cells) and occasionally in short chains in axial parenchyma cells, one crystal per cell or chamber.

Material studied: 7 specimens, B. coccinea Jacq., MADw 32265, B. grandiceps Jacq., MADw 4835, MADw 4836, MADw 11163, MADw 14229, MADw 32266, B. macrophylla Hort. ex Mast., MERw 1277.

\section{Copaifera L. - Fig. $3 \& 4$}

Growth rings distinct, marked by marginal parenchyma bands. Diffuse porous. Vessels solitary and in radial multiples of 2-4, 3-8 per $\mathrm{mm}^{2}, 90(100-190) 210 \mu \mathrm{m}$ in diameter, 100(253348) $480 \mu \mathrm{m}$ in element length. Simple perforation plates. Alternate intervessel pits small to medium, 6-10 $\mu \mathrm{m}$ in diameter. Vessel-ray pits with distinct borders, similar to intervessel pits in size and shape, pits vestured. Brown gumlike deposits in vessels. Fibres non-septate, medium-walled, 800(908-1264)1570 $\mu \mathrm{m}$ in length. Axial parenchyma vasicentric, aliform to confluent, aliform parenchyma of the lozenge type. Marginal parenchyma bands present. Axial parenchyma 2-4 cells per parenchyma strand. Rays mostly homocellular with typically procumbent cells to heterocellular, with 1 row of upright and/or square marginal cells, 6-8 per mm, 1 to 3 occasionally up to 4 cells wide, commonly less than $1 \mathrm{~mm}$, to slightly more than $1 \mathrm{~mm}$ : 220(250-691)1050 $\mu \mathrm{m}$ in height. Prismatic crystals common in chains in axial parenchyma cells, one crystal per cell or chamber. Intercellular canals axial in long tangential lines and connecting or immersed in bands of marginal parenchyma, $60-170 \mu \mathrm{m}$ in diameter.
Material studied: 13 specimens, C. officinalis (Jacq.) L., MERw 1533, MERw 1780, MERw 3297, MERw 5584, MERw 5585, MERw 5586, MERw 5587, MERw 5588, C. pubiflora Benth., MERw 4541, MERw 4542, MERw 4543, MERw 4544, MERw 4545.

Note: Metcalfe and Chalk (1950), Corothie (1967), Detienne et al. (1982), Richter and Dallwitz (2000) characterize the rays of Copaifera as homocellular (homogeneous), but Baretta-Kuipers (1981) described them as heterocellular. Additionally, JUNAC (1981) described homocellular rays $C$. officinalis and heterocellular rays in C. pubiflora. Mainieri and Chimelo (1989) report for C. cf. langsdorffii homocellular rays with tendency to heterocellular, and for $C$. cf. reticulate, heterocellular rays. Concerning fibres character JUNAC (1981), reports fibres partially septate, however, this feature was not observed in our specimens.

\section{Cynometra L. - Fig. 5 \& 6}

Growth rings indistinct marked by marginal parenchyma bands. Diffuse porous. Vessels solitary and in radial multiples of 2-4; occasionally clusters; 9-16 per $\mathrm{mm}^{2}$; 35(98104) $145 \mu \mathrm{m}$ in diameter, 150(264-331)450 $\mu \mathrm{m}$ in element length. Simple perforation plates. Alternate intervessel pits minute to small, 3-7 $\mu \mathrm{m}$ in diameter. Vessel-ray pits with distinct borders, similar to intervessel pits in size and shape; pits vestured. Brown gum-like deposits in vessels. Fibres non-septate, thick-walled, 1050(1375-1605)1950 $\mu \mathrm{m}$ in length. Axial parenchyma aliform to confluent, aliform parenchyma of the lozenge type, occasionally unilateral. Banded parenchyma mostly in bands more than three cells wide. Marginal parenchyma bands occasionally present. Axial parenchyma 2-4 cells per parenchyma strand. Rays heterocellular with 1 to 2 rows of upright and/or square marginal cells, rarely up to 3 marginal rows, $8-16$ per mm, 1 to 4 cells wide, 220(381-600)850 $\mu \mathrm{m}$ in height. Prismatic crystals common in upright and/or square ray cells and occasionally in short chains in 

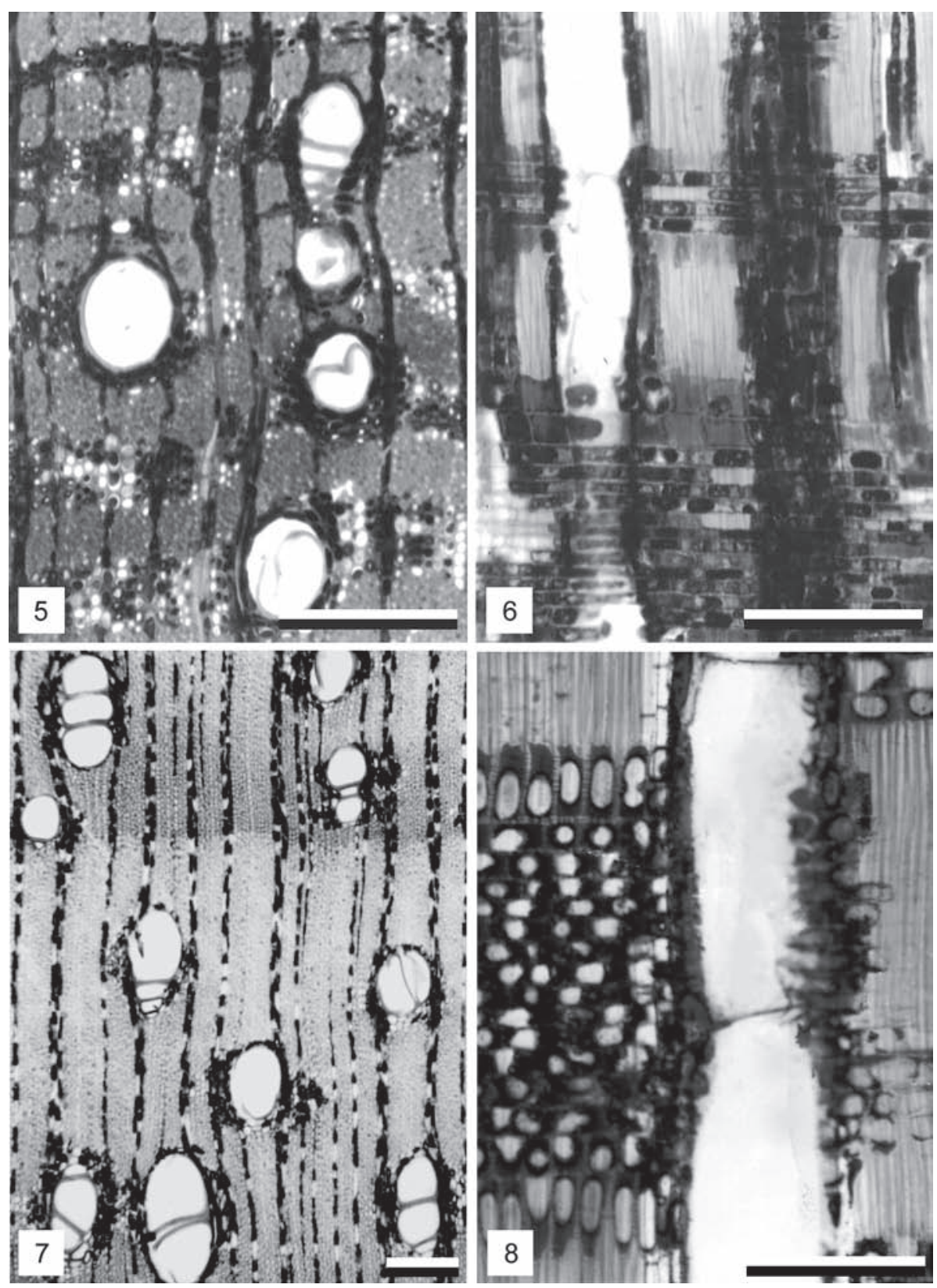

Fig. 5-8.- 5 \& 6: Cynometra spruceana .- 5: bands of parenchyma more than three cells wide.- 6: rays heterocellular, 1-2 rows of upright and/or square cells.- 7 \& 8: Dicymbe bernardii.- 7: growth rings distinct, aliform parenchyma.- 8: rays heterocellular, 1-2 rows of upright and/or square cells. Scale bars $=250 \mu \mathrm{m}$. 
axial parenchyma cells, one crystal per cell or chamber.

Material studied: 3 specimens, C. spruceana Benth., MADw 32048; C. sp. L. MERw 2152, MERw 2233.

Note: Metcalfe \& Chalk (1950) for Cynometra (except C. ramiflora) and Kribs (1968) for C. alexandri described the rays as homogeneous, but Baretta-Kuipers (1981); Richter \& Dallwitz (2000) for Cynometra and Detienne et al. (1982) for C. hostmanniana and C. parvifolia described the rays as heterocellular.

\section{Dicymbe Spruce ex Benth. - Fig. $7 \& 8$}

Growth rings distinct, marked by marginal parenchyma bands and/or thick-walled fibres. Diffuse porous. Vessels solitary and in radial multiples of 2-5; sometimes up to 9; occasionally some clusters, 4-6 per $\mathrm{mm}^{2}$; $80(121-150) 210 \mu \mathrm{m}$ in diameter, 200(307327)520 $\mu \mathrm{m}$ in element length. Simple perforation plates. Alternate intervessel pits small, 4-6 $\mu \mathrm{m}$ in diameter. Vessel-ray pits with distinct borders, similar to intervessel pits in size and shape; pits vestured. Brown gum-like deposits in vessels. Fibres non-septate, thick- to very thick-walled, 800(918-1600)2000 $\mu \mathrm{m}$ in length. Axial parenchyma mostly aliform, aliform parenchyma of the lozenge type, vasicentric, confluent. Marginal parenchyma bands absent in MERw 239 and present in MADw 31798. Axial parenchyma 3-4 cells per parenchyma strand. Rays mostly homocellular with typically procumbent cells to heterocellular, with 1-4 rows of upright and/or square marginal cells, 8-14 per mm, mostly 1 to 2 cells wide (occasionally 3 cells wide), 100(275-706)930 $\mu \mathrm{m}$ in height. Prismatic crystals occasionally present in upright and/or square ray cells and in short chains in axial parenchyma cells, one crystal per cell or chamber.

Material studied: 2 specimens, $D$. bernardii R.S Cowan, MERw 239; D. sp. MADw 31798.

Note: Metcalfe \& Chalk (1950) characterizes the rays of Dicymbe as homogeneous, but
Baretta-Kuipers (1981) described the rays as heterocellular.

Elizabetha Schomburgk ex Benth. - Fig. 9 \& 10

Growth rings distinct, marked by marginal parenchyma bands and/or thick-walled fibres. Diffuse porous. Vessels solitary and in radial multiples of $2-3$, sometimes up to 5 , occasionally some clusters, 5-10 per $\mathrm{mm}^{2}$, $70(110-130) 150 \mu \mathrm{m}$ in diameter, 200(320$355) 490 \mu \mathrm{m}$ in element length. Simple perforation plates. Alternate intervessel pits small, 4-5 $\mu \mathrm{m}$ in diameter. Vessel-ray pits with distinct borders, similar to intervessel pits in size and shape, pits vestured. Brown gum-like deposits in vessels. Fibres non-septate, mediumto thick-walled, 950(1240-1365)1580 $\mu \mathrm{m}$ in length. Axial parenchyma aliform to confluent, aliform parenchyma of the lozenge type, occasionally vasicentric. Banded parenchyma mostly in bands 3-5 cells wide. Marginal parenchyma bands present. Axial parenchyma 3-4 cells per parenchyma strand. Rays heterocellular with 1 to 2 rows of upright and/ or square marginal cells, 7-10 per mm, exclusively or mostly uniseriate, 110(220-230)420 $\mu \mathrm{m}$ in height. Prismatic crystals common in procumbent ray cells (occasionally in upright and/or square) and occasionally in short chains in axial parenchyma cells, one crystal per cell or chamber.

Material studied: 2 specimens, E. princeps Schomburgk ex Benth., MADw 31823, E. macrostachya Benth., MERw 5275.

\section{Eperua Aublet. - Fig. 11 \& 12}

Growth rings distinct marked by marginal parenchyma bands. Diffuse porous. Vessels solitary and in radial multiples of 2-3, sometimes up to 8 , occasionally some clusters, $3-13$ per $\mathrm{mm}^{2}$, 70(155-235) $300 \mu \mathrm{m}$ in diameter, 200(364-436) $600 \mu \mathrm{m}$ in element length. Simple perforation plates. Alternate intervessel pits circular or oval and poligonal, small to medium, 4-8 $\mu \mathrm{m}$ in diameter. Vessel-ray pits with distinct borders, similar to intervessel pits in size and shape, pits vestured. Brown 

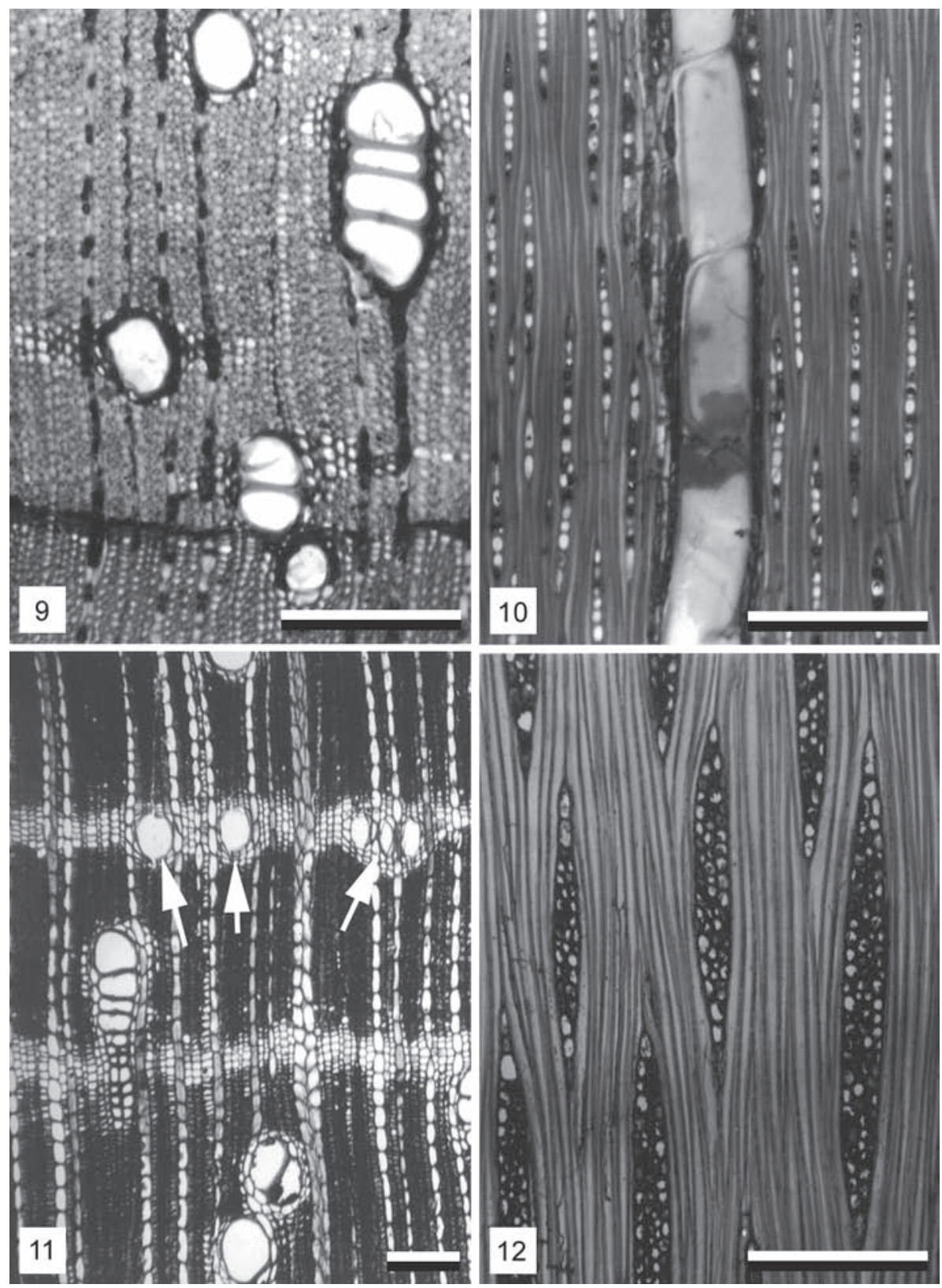

Fig. 9-12.- 9 \& 10: Elizabetha princeps.-- 9: growth rings distinct, marked by thick-walled fibres and aliform parenchyma.10: rays exclusively uniseriate.-- 11 \& 12: Eperua species.- 11: E. leucantha, intercellular axial canals (arrow), in long tangential lines and connecting or immersed in bands of marginal parenchyma.- 12: E. purpurea, rays mostly 3-4 wide cells. Scale bars $=250 \mu \mathrm{m}$. 
gum-like deposits in vessels. Fibres non-septate, medium-walled, 970(1104-1459)1600 $\mu \mathrm{m}$ in length. Axial parenchyma scanty, vasicentric thin, sometimes diffuse-in-aggregates. Marginal parenchyma bands present. Axial parenchyma 3-4 cells per parenchyma strand. Rays heterocellular with 1 to 4 rows of upright and/or square marginal cells, 5-8 per mm, 1 to 4 cells wide, 180(200-510)750 $\mu \mathrm{m}$ in height. Prismatic crystals common in long chains in axial parenchyma cells, one crystal per cell or chamber. Intercellular axial canals in long tangential lines and connecting or immersed in bands of marginal parenchyma, occasionally diffuse (E. purpurea), 50-150 $\mu \mathrm{m}$ in diameter.

Material studied: 4 specimens, E. grandiflora (Aubl.) Benth., MERw 200, E. leucantha Benth., MERw 194, E. purpurea Benth., MERw 5273, MERw 5276.

\section{Heterostemon Desf. - Fig. 13 \& 14}

Growth rings distinct, marked by marginal parenchyma bands and thick-walled fibres. Diffuse porous. Vessels solitary and radial multiples of 2-3, sometimes up to 5 , occasionally some clusters, 7-15 per $\mathrm{mm}^{2}, 50(73-98) 140 \mu \mathrm{m}$ in diameter, 160(264-322)430 $\mu \mathrm{m}$ in element length. Simple perforation plates. Alternate intervessel pits circular or oval of them shape polygonal, minute to small, 3-6 $\mu \mathrm{m}$ in diameter. Vessel-ray pits with distinct borders, similar to intervessel pits in size and shape, pits vestured. Brown gum-like deposits in vessels. Fibres non-septate, medium- to thick-walled, 700(740-949)1240 $\mu \mathrm{m}$ in length. Axial parenchyma vasicentric, aliform to confluent, aliform parenchyma of the lozenge type. Banded parenchyma occasionally more than three cells wide in $H$. conjugatus. Marginal parenchyma bands present. Axial parenchyma 2-4 cells per parenchyma strand. Rays heterocellular with 1 to 4 rows of upright and/or square marginal cells, occasionally 5 in $H$. conjugatus, 7-17 per $\mathrm{mm}$, exclusively or mostly uniseriate, 170(250517)640 $\mu \mathrm{m}$ in height. Prismatic crystals not common, mostly present in procumbent ray cells, one crystal per cell or chamber.
Material studied: 6 specimens, $H$. cauliflorus Pittier, MADw 31929, MADw 31931, H. conjugatus Spruce ex Benth., MERw 5283, MADw 31932, MADw 31933, H. mimosoides Desf., MADW 31934.

\section{Hymenaea L. - Fig. $15 \& 16$}

Growth rings distinct, marked by marginal parenchyma bands and beside very thick-walled fibres in $H$. oblongifolia. Diffuse porous. Vessels solitary and radial multiples of 2-4, occasionally some clusters, 2-3 per $\mathrm{mm}^{2}$, $90(132-202) 300 \mu \mathrm{m}$ in diameter, 160(238354)520 $\mu \mathrm{m}$ in element length. Simple perforation plates. Alternate intervessel pits circular or oval, of them shape polygonal, small, 4-7 $\mu \mathrm{m}$ in diameter. Vessel-ray pits with distinct borders, similar to intervessel pits in size and shape, pits vestured. Reddish brown gum-like deposits in vessels. Fibres non-septate, thickto very thick-walled, 1000(1340-1525)1890 $\mu \mathrm{m}$ in length. Axial parenchyma mostly aliform to confluent, aliform parenchyma of the lozenge type. Banded parenchyma of more than three cells wide in $H$. courbaril and $H$. oblongifolia. Marginal parenchyma bands present. Axial parenchyma 2-4 cells per parenchyma strand. Rays homocellular with typically procumbent cells (marginal cells sometimes slightly enlarged), 3-8 per mm, 1 to 6 cells wide, 110(192-450)650 $\mu \mathrm{m}$ in height. Prismatic crystals common in long chains in chambered axial parenchyma cells, one crystal per cell or chamber.

Material studied: 11 specimens, $H$. courbaril L., MERw 1507, MERw 3394, MERw 4564, MERw 4565, MERw 4566, MERw 4567, MERw 2489, H. oblongifolia Huber, MERw 2087, MERw 2533, MERw 2648, $H$. parvifolia Huber, MERw 2053.

\section{Macrolobium Schreber. - Fig. 17 \& 18}

Growth rings distinct, marked by marginal parenchyma bands and/or thick-walled fibres. Diffuse porous. Vessels solitary and radial multiples of 2-3, sometimes up to 8, occasionally some clusters, $2-13$ per $\mathrm{mm}^{2}, 60$ (85-177) 

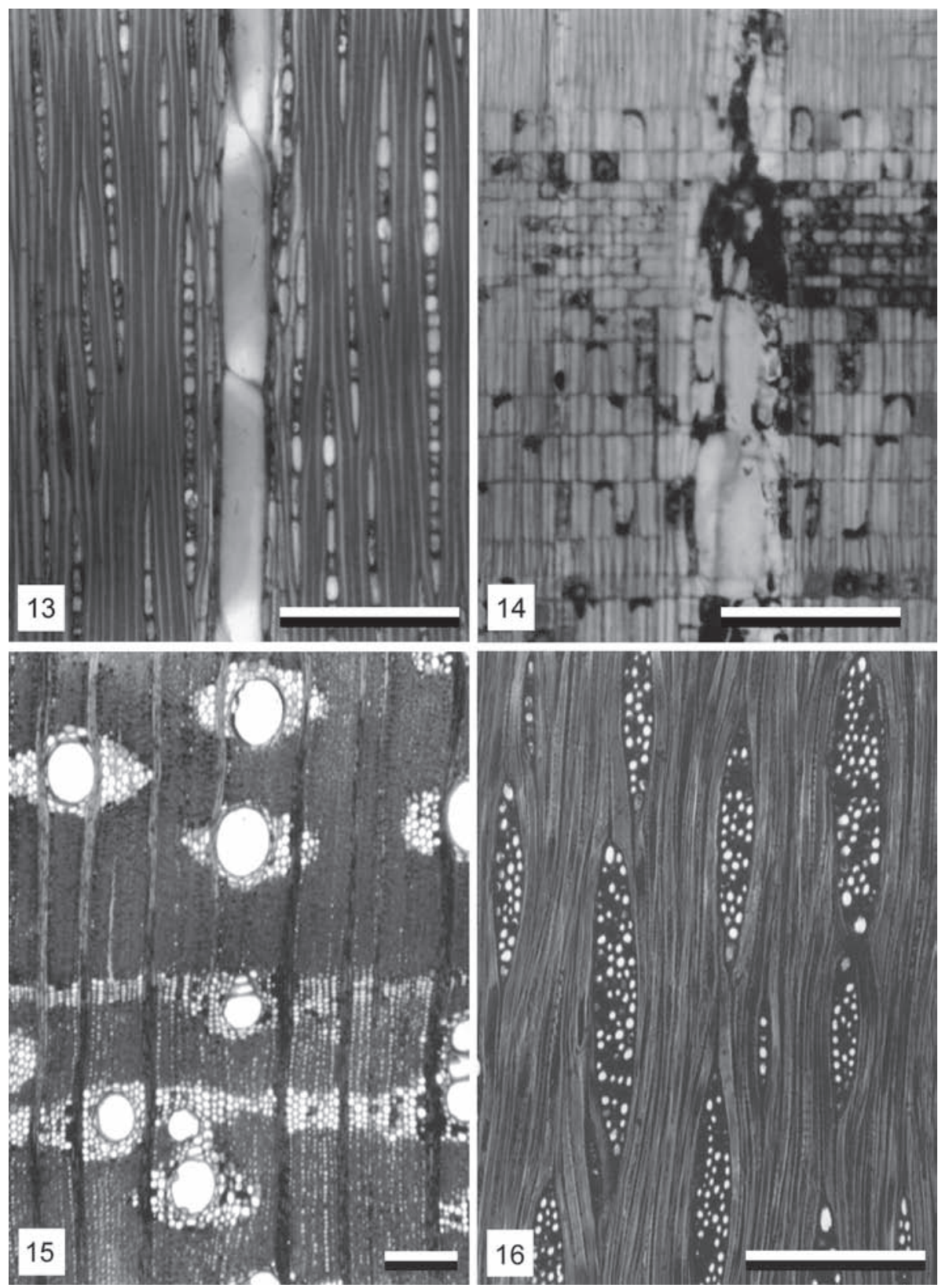

Fig. 13-16.- 13 \& 14: Heterostemon species.- 13: H. cauliflorus, rays exclusively uniseriate.- 14: H. conjugatus, rays heterocellular, 2-4 rows of upright and/or square cells.- 15 \& 16: Hymenaea courbaril- 15: aliform, confluent parenchyma and marginal banded.- 16: rays mostly 1-6 wide cells. Scale bars $=250 \mu \mathrm{m}$. 

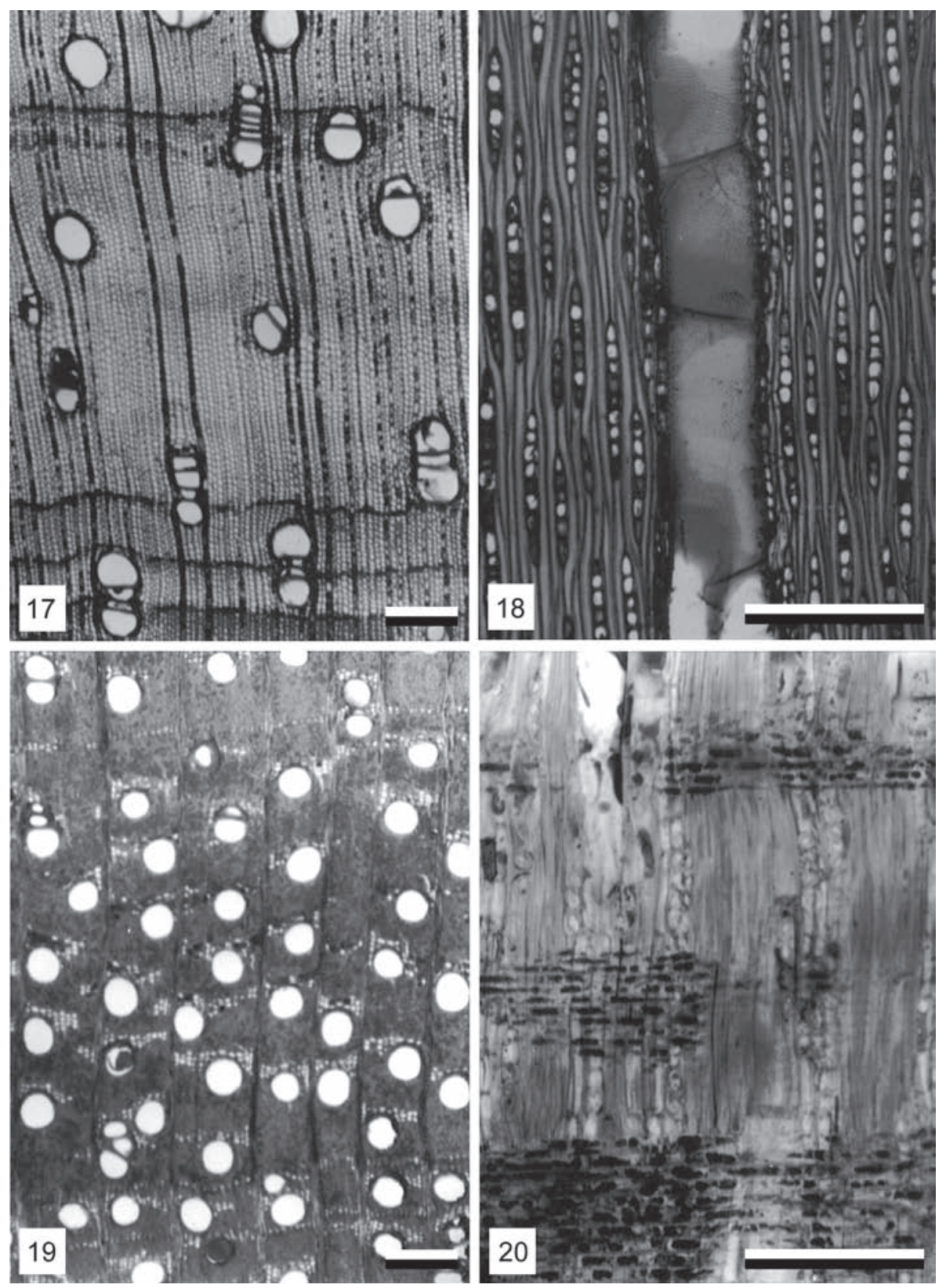

Fig. 17-20.- 17 \& 18: Macrolobium species.- 17: M. angustifolium, growth rings distinct, marked by thick-walled fibres, vasicentric and aliform parenchyma.- 18: M. molle, rays mostly uniseriate.- 19 \& 20: Peltogyne species.- 19: P. paniculata, aliform to confluent, unilateral parenchyma and banded parenchyma in narrow bands or lines, up to three cells wide.- 20: $P$. porphyrocardia, rays homocellular, composed of typically procumbent cells. Scale bars $=250 \mu \mathrm{m}$. 
$230 \mu \mathrm{m}$ in diameter, 133 (236-439) $590 \mu \mathrm{m}$ in element length. Simple perforation plates. Alternate intervessel pits circular or oval and polygonal, small, 5-8 $\mu \mathrm{m}$ in diameter. Vessel-ray pits with distinct borders, similar to intervessel pits in size and shape, pits vestured. Brown gumlike deposits in vessels. Fibres non-septate, thin-walled to thick-walled, 670(817-1765)2350 $\mu \mathrm{m}$ in length. Axial parenchyma vasicentric, aliform to confluent, aliform parenchyma of the lozenge type. Banded parenchyma of 2-4 cells wide. Marginal parenchyma bands present. Axial parenchyma 2-5 cells per parenchyma strand. Rays heterocellular with 1 to 2 rows of upright and/or square marginal cells (sometimes to 3), 9-20 per mm, exclusively or mostly uniseriate in M. gracile, M. limbatum, M. molle and $M$. rubrum, uniseriate and biseriate in $M$. acaciifolium, M. angustifolium, M. multijugum and M. punctatum, 100(220-390)650 $\mu \mathrm{m}$ in height. Storied structure not observed, only rays irregularly storied (rays in echelon) in M. molle. Prismatic crystals common in ray cells (both upright and/or square ray cells and procumbent cells) and occasionally in short chains in axial parenchyma cells in $M$. angustifolium, M. gracile, M. limbatum, M. molle, M. multijugum and M. punctatum. Prismatic crystals common in axial parenchyma cells and sporadic in ray cells in M. acaciifolium and M. rubrum, one to occasionally two crystals per cell or chamber.

Material studied: 15 specimens, $M$. acaciifolium (Benth.) Benth., MERw 2084, MERw 3374, MADw 14917, M. angustifolium (Benth.) Cowan, MADw 31604, MADw 31617, MADw 31620, M. gracile Spruce ex Benth., MADw 31611, M. limbatum Spruce ex Benth., MERw 2050, M. molle (Benth.) Cowan, MADw 14912, MADw 31613, MADw 31614, M. multijugum (DC.) Benth., MADw 31605, MADw 31612, M. punctatum Spruce ex Benth., MERw 2021, M. rubrum R.S Cowan, MADw 22398.

\section{Peltogyne Vogel. - Fig. 19 \& 20}

Growth rings distinct, marked by marginal parenchyma bands in $P$. paniculata but absent in P. floribunda. Diffuse porous. Vessels solitary and in radial multiples of 2-3, sometimes up to 5, occasionally some clusters, 20-46 per $\mathrm{mm}^{2}, 50(60-120) 140 \mu \mathrm{m}$ in diameter, 200 (260-390) $420 \mu \mathrm{m}$ in element length. Simple perforation plates. Alternate intervessel pits circular or oval, of them shape polygonal, small to medium, 5-8 $\mu \mathrm{m}$ in diameter. Vessel-ray pits with distinct borders, similar to intervessel pits in size and shape, pits vestured. Reddish brown gum-like deposits in vessels. Fibres non-septate, very thick-walled, 860(12081700) $1820 \mu \mathrm{m}$ in length. Axial parenchyma mostly aliform to confluent, aliform parenchyma of the winged type, unilateral. Banded parenchyma in narrow bands or lines, up to three cells wide. Marginal parenchyma bands present in P. paniculata. Axial parenchyma 3-5 cells per parenchyma strand. Rays homocellular with typically procumbent cells, 5-10 per $\mathrm{mm}, 2$ to 4 cells wide, 140(160-480)830 $\mu \mathrm{m}$ in height. Storied structure in axial parenchyma in $P$. paniculata and irregularly storied in axial parenchyma in P. floribunda. Prismatic crystals common in chains in chambered axial parenchyma cells, one crystal per cell or chamber. Intercellular canals of traumatic origin present in P. floribunda.

Material studied: 7 specimens, $P$. paniculata Benth., MERw 1760, MERw 2463, P. floribunda (Kunth) Pittier, MERw 1524, MERw 1771, MERw 4568, MERw 4569, MERw 4570.

Note: Metcalfe and Chalk (1950) mention tendencies to storied axial parenchyma in some species of Peltogyne. This feature was also found in P. floribunda (= P. porphyrocardia) by JUNAC (1981), but is not mentioned by Corothie (1967) for the same specie and by 
Detienne et al. (1982) and Nardi and Edlmann (1992) for P. paniculata. However, other species of the genus were described by Kribs (1968) for P. densiflora, Detienne et al. (1982) and Miller and Détienne (2001) for P. venosa, all with storied structure not observed.

\section{DISCUSSION}

All wood characters have been recorded, but only the most systematically and diagnostically important ones are displays in Table 1 and the following discussion. These characters emphasized the anatomical information to help in the identification of the species and genera of the Venezuelan Detarieae. Diagnostic features for reliable identification and potentially phylogenetically valuable information within the tribe Detarieae include: fibre wall thickness, ray composition, ray width, intercellular axial canals and storied structure, parenchyma type and prismatic crystals in ray cells. Quantitative features also vary (see Table 1), but most vary too much to be useful in identifications or comparisons. The exceptions are vessels per $\mathrm{mm}^{2}$ (e.g. species of Peltogyne) ray width (e.g. species of Hymenaea) and intervessel pit size. Vessels per $\mathrm{mm}^{2}$ and ray width are a good diagnostic quantitative character in these groups.

\section{Comparison of Detarieae with Caesalpinieae}

All legume woods have simple perforation plates, alternate intervessel pitting, vessel-ray pits similar to intervessel pits in size and shape, fibres with simple pits, vestured pits (with some exceptions) and in general axial parenchyma with mostly 2-4 cells per strand. In general, the species of the subfamily Caesalpinioideae have medium to thick fibre walls, aliform, confluent and marginal parenchyma, homocellular rays or with a row of square or upright marginals cells, biseriate rays non-storeyed and prismatic crystals in chambered axial parenchyma cells (Baretta-Kuipers 1981, Höhn 1999, Herendeen 2000, Gasson et al. 2003, Espinoza de Pernía and Melandri 2006a,b). While, the following wood characters provide the most systematically important characters between Detarieae and Caesalpinieae:

Fibres: septate only in Schizolobium (Caesalpinieae) and are absent in Detarieae genera. Usually thin to thick walled in Detarieae and thick and very thick in the most of Caesalpinieae.

Rays: there is considerable variation in ray cell composition and ray width between taxa. Homocellular rays are most common in Caesalpinieae, while in Detarieae, most common rays are heterocellular. Concerning width ray, in agreement with Metcalfe and Chalk (1950), Baretta and Kuipers (1981), Détienne and Welle (1989), Mainieri and Peres (1989), Miller and Détienne (2001) and Gasson et al. (2003), we observed in both tribes two groups: 1) Uniseriate (exclusively or predominantly) to biseriate rays in Brownea, Elizabetha, Heterostemom, Macrolobium, Sclerolobium subbullatum and Tachigali. 2) Multiseriate rays in Caesalpinia, Campsiandra, Copaifera, Cynometra, Delonix regia, Dimorphandra, Dicymbe, Eperua, Hymenaea, Mora, Peltogyne and Schizolobium.

Intercellular axial canals: the presence and distribution of axial canals is a good diagnostic and systematic character in Detarieae. They are found in long tangential lines and immersed in bands of marginal parenchyma in Copaifera and Eperua (Detarieae tribe), also reported and discussed by Barettta-Kuipers (1981), Détienne et al. (1982), Détienne and Welle (1989), Miller and Détienne (2001) and Gasson et al. (2003), occasionally diffuse in Eperua purpurea, absent in all Caesalpinieae genera.

Axial parenchyma in narrow bands uncommon in both tribes, however, common in Caesalpinia coriaria, C. ebano of Caesalpinieae tribe and Macrolobium gracile, M. limbatum, M. molle, Peltogyne floribunda, P. paniculata and occasionally in Hymenaea oblongifolia and Macrolobium acaciifolium of Detarieae tribe. Bands more than three cells wide in Caesalpinia granadillo, C. sclerocarpa, Campsiandra, Dimorphardra cuprea 


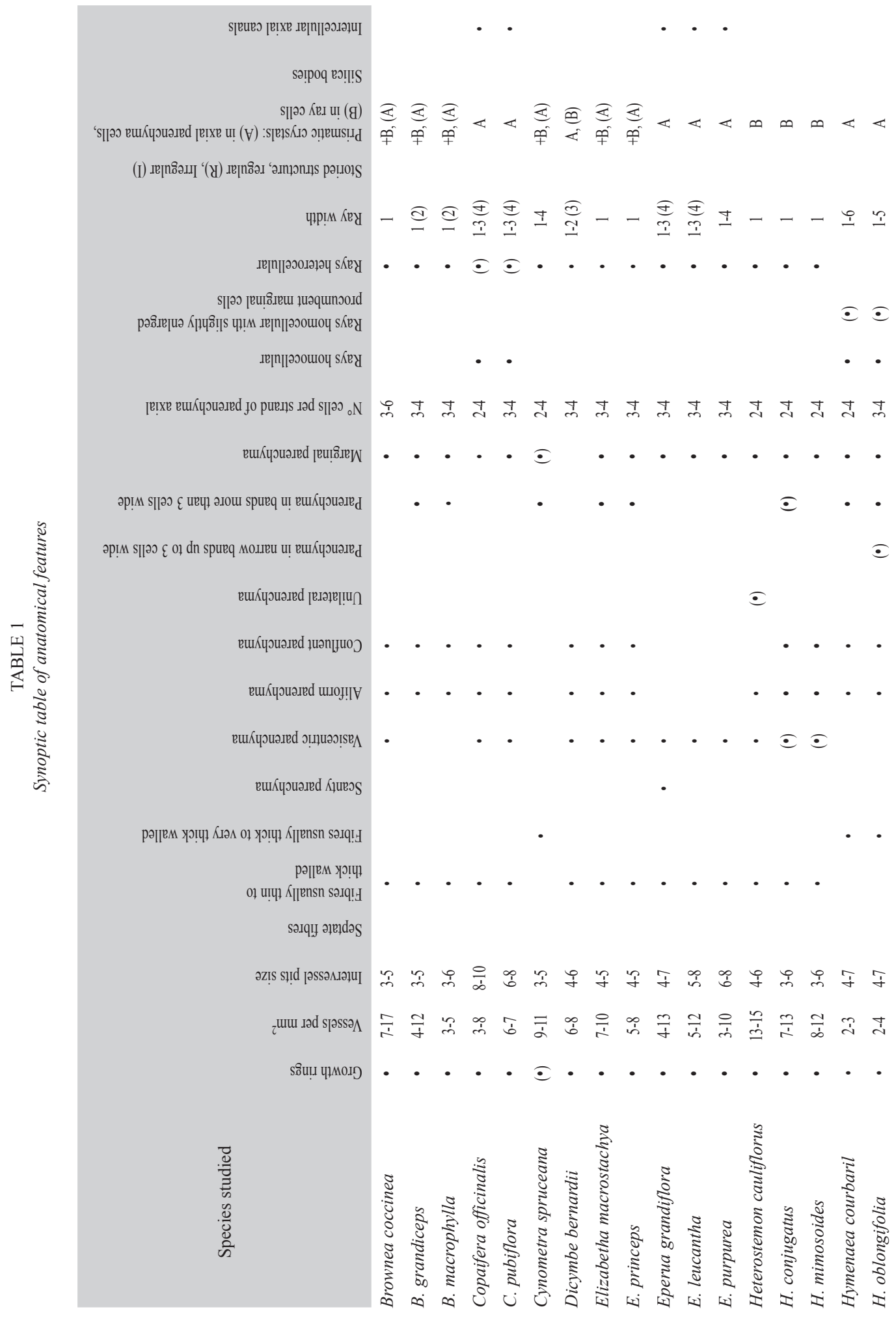




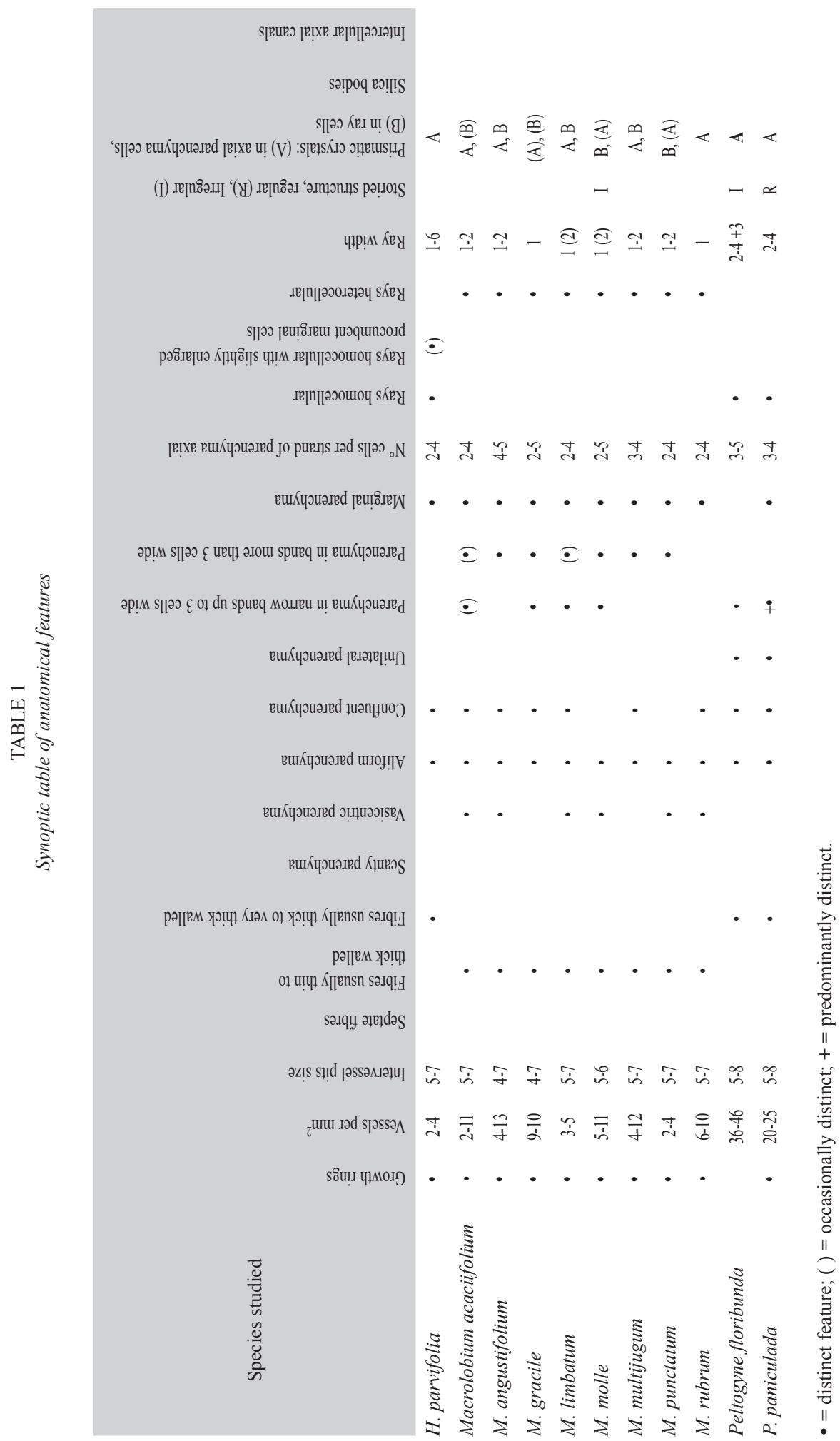


subsp. ferruginea, D. davisii, Mora gonggrijpii, of Caesalpinieae tribe and Brownea grandiceps, B. macrophylla, Cynometra spruceana, Elizabetha, Hymenaea courbaril, H.oblongifolia, Magrolobium angustifolia, M. gracile, M. molle, M. multijugum, M. punctatum of Detarieae tribe. Storeying in axial parenchyma in $P$. paniculata storied and $P$. floribunda irregularly storied, but rays never storied in Detarieae tribe. Storied structure in all the cell types only occurs in Caesalpinia.

Prismatic crystals are common in subfamily Caesalpinioideae, particularly frequent in axial parenchyma cells, however a of number important genera of the Detarieae tribe also have prismatic crystals common in ray cells, usually one crystal per cell or chamber: Brownea, Cynometra, Dicymbe, Elizabetha, Heterostemon and Macrolobium (except $M$. rubrum). This observation coincides with recorded by Détienne et al. (1982), Détienne and Welle (1989), Miller and Détienne (2001). Silica bodies only present in the tribe Caesalpinieae (Tachigali and Sclerolobium species), absent in all Detarieae studied, also discussed by Koeppen (1980), Barettta-Kuipers (1981) and Gasson et al. (2003).

Vessels per $\mathrm{mm}^{2}$ of 2 to 10 in most species of Caesalpinieae and Detarieae tribes, however Peltogyne is very different, presents from 20 to 46 per $\mathrm{mm}^{2}$. Intervessel pit size in most Caesalpinieae and Detarieae is commonly medium to large, while in Brownea, Cynometra, Dimorphandra, Heterostemon and Mora, there is a tendency towards minute to small.

Finally, in summary the diagnostic features important for identification of the tribe Detarieae and for comparison with Caesalpinieae are: intercellular axial canals, rays heterocellular, rays exclusively or predominantly uniseriate, prismatic crystals common in ray cells, storied structure, fibre wall thickness and absent of silica bodies. The interpretation of homocellular versus heterocellular rays in Copaifera, Cynometra and Dicymbe is not consistent in the literature with similar inconsistencies for the tribe Caesalpinieae (Espinoza de Pernía and Melandri 2006b). Therefore, this character may need to be re-examined in the wood of other legumes and possibly re-defined for use in keys and descriptions. In addition, the distribution of these diagnostic features in particular groups, often in agreement with phylogenies and also certain characters may have some relationship to ecological conditions (e.g. vessels per $\mathrm{mm}^{2}$, intervessel pit size, axial parenchyma abundance and fibre wall thickness).

\section{ACKNOWLEDGMENTS}

We thank Regis B. Miller, USDA Forest Service, Forest Products Laboratory, Madison, Wisconsin for helpful suggestions and also for providing the sectioning blocks of some materials studied. For the financial help we wish to thank C.D.C.H.T of the Universidad de Los Andes (Project: FO-392-96-01-B), Mérida, Venezuela.

\section{RESUMEN}

Se estudió la anatomía de la madera de 29 especies de 10 géneros de la tribu Detarieae, subfamilia Caesalpinioideae, enfocado hacia la identificación de la estructura de la madera y su comparación con la tribu Caesalpinieae. Los especímenes fueron recolectados en Venezuela y pertenecen a la colecciones de maderas del Laboratorio de Anatomía de Maderas de la Facultad de Ciencias Forestales y Ambientales de la Universidad de Los Andes, Mérida, Venezuela y del USDA Forest Service, Forest Products Laboratory, Madison, Wisconsin, USA. Las características anatómicas evaluadas siguen lo propuesto por IAWA List of Microscopic Features for Hardwood Identification (IAWA Committee 1989). Las especies de la tribu Detarieae pueden ser identificadas usando un número de características de diagnóstico combinadas: canales intercelulares longitudinales, radios heterocelulares exclusiva o predominantemente uniseriados, patrones del parénquima axial, cristales prismáticos en las células radiales, estructura estratificada y grosor de las paredes de las fibras. Estos caracteres también proporcionan una valiosa información para estudios sistemáticos y filogenéticos. Se presenta la descripción anatómica a nivel de género, una tabla sinóptica con los caracteres de diagnóstico principales y fotomicrografías de las características más importantes.

Palabras claves: Leguminosae, Caesalpinioideae, Detarieae, Caesalpinieae, anatomía de la madera, identificación. 


\section{REFERENCES}

Aristeguieta, L. 2003. Estudio dendrológico de la Flora Venezolana. Vol. XXXVIII. Academia de Ciencias Físicas, Matemáticas y Naturales. Caracas, Venezuela.

Baretta-Kuipers, T. 1981. Wood anatomy of Leguminosae: its relevance to taxonomy, p. 677-705. In R.M. Polhill \& P.H. Raven (eds), Advances in Legume Systematics, Part 2, Royal Botanic Gardens, Kew, England.

Barneby, R., B. Stergios, R. Cowan, P. Berry, J. Zarucchi, R. Wunderlin, D. Kearns, M.F da Silva, A. Sprada, D. Velaázquez, N. Xena \& G. Aymard. 1998. Caesalpiniaceae, p. 1-121. In Berry P., B. Holst \& K. Yatskievych (eds). Flora of the Venezuelan Guayana. Vol. 4. Missouri Botanical Garden, St. Louis, Missouri.

Bruneau, A., F.J. Breteler, J.J. Wieringa, G.Y.F. Gervais and F. Forest. 2000. Phylogenetic relationships in tribes Macrolobieae and Detarieae as inferred from chloroplast $t r n \mathrm{~L}$ intro sequences. In P.S. Herendeen and A. Bruneau (eds), Advances in Legume Systematics, Part 9: 121-149. Royal Botanic Gardens, Kew, England.

Chauhan, L. \& R.V. Rao. 2003. Wood anatomy of legumes of India: their identification, properties and uses. Bishen Singh Mahendra Pal Singh, Dehra-Dun, India.

Corothie, H. 1967. Estructura anatómica de 47 maderas de la Guayana Venezolana. Laboratorio Nacional de Productos Forestales. Universidad de los Andes Ministerio de Agricultura y Cría. Mérida, Venezuela.

Détienne, P. \& B.J.H. ter Welle. 1989. Wood and timber. In R.S. Cowan \& J.C Lindemann (A.R.A. Gorts ven Rijn, editor) Flora of the Guianas 88 Caesalpinieae, 123-149. Koeltz Scientific, Koenigstein, Germany.

Détienne, P., P. Jacquet \& A. Mariaux. 1982. Manuel d' identification des bois tropicaux. Tome 3. Guyana Française. Centre Technique Forestier Tropical, Nogent-sur-Marne, France.

Espinoza de Pernía, N. \& J.L. Melandri. 2006a. Anatomía de la madera de 68 especies de la subfamilia Caesalpinioideae (Leguminosae) en Venezuela. Universidad de Los Andes. Consejo de Desarrollo Científico, Humanístico y Tecnológico (CDCHT). Mérida, Venezuela.

Espinoza de Pernía, N. \& J.L. Melandri. 2006b. Wood anatomy of the tribe Caesalpinieae (Leguminosae, Caesalpinioideae) in Venezuela. IAWA J. 27: 99-114.
Gasson, P. 1994. Wood anatomy of the tribe Sophoreae and related Caesalpinioideae and Papilionoideae. In I.K. Fergunson \& S. Tucker (eds), Advances in Legume Systematics, Part 6: 165-203, Royal Botanic Gardens, Kew, England.

Gasson, P. 1996. Wood anatomy of the tribe Swartzieae with comments on related Papilionoid and Caesalpinioid Leguminosae. IAWA J. 17: 45-75.

Gasson, P. 1999. Wood anatomy of the tribe Dipterygeae with comments on related Papilionoid and Caesalpinioid Leguminosae. IAWA J. 20: 441-455.

Gasson P., C. Trafford \& B. Matthews. 2003. Wood anatomy of Caesalpinioideae. In: B.B. Klitgaard and A. Bruneau (eds). Advances in Legume Systematics, Part 10: 63-93. Royal Botanic Gardens, Kew, England.

Herendeen, P.S. 2000. Structural evolution in Caesalpinioideae (Leguminosae). In P.S. Herendeen and A. Bruneau (eds), Advances in Legume Systematics, Part 9: 45-64, Royal Botanic Gardens, Kew, England.

Herendeen, P.S., A. Bruneau \& G.P. Lewis. 2003. Phylogenetic relationships in Caesalpinioid Legumes: A preliminary analysis based on morphological and molecular data. In B. B. Klitgaard and A. Bruneau, Editors. Advances in Legume Systematics, part 10, 37-62. Royal Botanic Gardens, Kew, England.

Höhn, A. 1999. Wood anatomy of selected West African species of Caesalpinioideae and Mimosoideae (Leguminosae): a comparative study. IAWA J. 20: 115-146.

IAWA Committee. 1989. IAWA list of microscopic features for hardwood identification. IAWA Bull. n.s. 10: 219-332.

INIA. 1996. Manual de identificación de especies forestales de la subregión Andina. Instituto Nacional de Investigaciones Agrarias. Lima, Perú.

JUNAC. 1981. Descripción general y anatómica de 105 maderas del grupo Andino. PADT-REPORT, Junta del acuerdo de Cartagena (JUNAC). Lima, Perú.

Koeppen, R.C. 1980. Silica bodies in wood of arborescent Leguminosae. IAWA Bull. n.s. 1: 180-184.

Kribs, D.A. 1968. Commercial foreign woods on the American Market. Dover Publications. New York, USA. 
Mabberley, D.J. 1997. The plant-book. A portable dictionary of the vascular plants. Cambridge University, United Kingdom.

Mainieri, C. \& J.P. Chimelo. 1989. Fichas de características das madeiras brasileiras. Instituto de Pesquisas Tecnológicas. Divisao de Madeiras. Sao Paulo, Brasil.

Metcalfe, C.R. \& L. Chalk. 1950. Anatomy of the dicotyledons. Vol. I. Clarendon, Oxford. England.

Miller, R.B. \& P. Détienne. 2001. Mayor timber trees of Guyana. Wood anatomy. Tropenbos Series 20 The Tropenbos Foundation, Wageningen, The Netherlands.

Nardi Berti, R. \& M. Edlmann Abbate. 1992. Legnami tropicali importati in Italia: anatomia e identificazione. Vol. II. América Latina. C.N.R: Firenze, Italia.
Ranjani, K. \& K.V. Krishnamurthy. 1988. Nature of vestures in the vestured pits of some Caesalpiniaceae. IAWA Bull. n.s. 9: 31-33.

Reinders-Gouwentak, C. A. 1955. The storied-structurefeatures and the taxonomic rank of the leguminous taxa. Acta Bot. Neerl. 4: 460-470.

Richter, H.G \& M.J. Dallwitz. 2000. Commercial timbers: descriptions, illustrations, identification and information retrieval. [Online]. In English, French, German and Spanish. Version: 18th October 2002. Available: http://biodiversity.uno.edu/delta/ [24 May 2006].

Wheeler, E. \& Baas, P. 1992. Fossil wood of the Leguminosae: a case study in xylem evolution and ecological anatomy. In P.S Herendeen \& D.I. Dilcher (eds), Advances in Legume Systematics, Part 4, The Fossil Record, pp. 281-301, Royal Botanic Gardens, Kew, England. 
